\title{
PENINGKATAN HASIL BELAJAR DAN KEMANDIRIAN SISWA PADA MATA PELAJARAN IPA MENGGUNAKAN MODEL PEMBELAJARAN KOOPERATIF TIPE THINK PAIR SHARE (TPS) KELAS 4 SD
}

\author{
Rusiana Kumala Dewi, Firosalia Kristin \\ Surel: 292013167@ student.uksw.edu
}

\begin{abstract}
This study aims to improve student learning outcomes and independence through cooperative learning model Think Pair Share (TPS). The method of this research is Classroom Action Research (PTK) which consists of two cycles starting with planning, implementation, observation and reflection. Collection of test and non test data. The results showed an increase in learning outcomes and independence. In cycle one average learning outcomes 75.62 completeness value $75 \%$ completeness score. In cycle 2 the average learning outcomes increased to 83.75, completeness value 91.6. The result of independence in cycle 1 indicates self-sufficiency "Enough" (75\%), in cycle 2 shows independence "Very Good" (91.6\%).
\end{abstract}

Keywords: Learning Outcomes, Think Pair Share (TPS), Student Independence

\begin{abstract}
ABSTRAK
Penelitian ini bertujuan untuk meningkatkan hasil belajar dan kemandirian siswa melalui model pembelajaran kooperatif tipe Think Pair Share (TPS). Metode penelitian ini adalah Penelitian Tindakan Kelas (PTK) yang terdiri dari dua siklus yang diawali dengan tahap perencanaan, pelaksanaan, pengamatan (observasi), dan refleksi. Pengumpulan data tes dan non tes. Hasil penelitian menunjukkan peningkatan hasil belajar dan kemandirian. Pada siklus satu rata-rata hasil belajar 75,62 nilai ketuntasan $75 \%$. Pada siklus 2 rata-rata hasil belajar meningkat menjadi 83,75, Nilai ketuntasan 91,6. Hasil kemandirian pada siklus 1 menunjukkan kemandirian "Cukup" (75\%), pada siklus 2 menunjukkan kemandirian "Sangat Baik" $(91,6 \%)$.
\end{abstract}

Kata Kunci : Hasil Belajar, Think Pair Share (TPS), Kemandirian Siswa

\section{PENDAHULUAN}

Sekolah adalah suatu lembaga yang secara formal bertanggungjawab atas keberlangsungan proses pendidikan. Di tingkat pendidikan SD banyak sekali mata pelajaran yang harus dikuasai siswa, salah satunya adalah mata pelajaran IPA. Pelajaran IPA sangat penting karena dengan mempelajari IPA manusia akan lebih peduli dan menjaga lingkunganya. Hal ini sangat berpengaruh bagi kelangsungan kehidupan. Selain itu IPA adalah sala satu dari mata pelajaran yang diujikan dalam Ujian Akhir Nasional, hal ini berarti IPA sangat penting untuk syarat kelulusan

Jurusan PGSD FKIP Universitas Kristen Satya Wacana 
siswa. Karena hal itu, maka mata pelajaran ini perlu dikembangkan lebih dalam lagi dengan model pembelajaran yang tepat supaya siswa lebih mudah mengerti.

Dari wawancara dengan guru kelas 4 SD Negeri Blotongan 03, rata - rata hasil belajar IPA pada UTS berada dibawah KKM (Kriteria Ketuntasan Minimal) yang seharusnya mencapai nilai 70 di SD Negeri Blotongan 03. Hasil belajar menunjukkan bahwa dari 24 siswa kelas 4, 10 siswa $(46,2 \%)$ tidak tuntas karena mendapatkan nilai dibawah 70 , dan 14 siswa $(53,8 \%)$ mendapatkan nilai diatas 70 rata-rata pada pra siklus hanya 62,70 . Hal ini karena terdapat kekurangan dalam model yang diterapkan dalam kegiatan pembelajaran. Guru cenderung menggunakan model pembelajaran konvensional seperti ceramah. Model pembelajaran ini kurang memberi kesempatan siswa untuk berfikir kritis, aktif dan mandiri. Siswa menjadi cenderung lebih individual. Penerapan metode ceramah membuat siswa bosan dan kurang tertarik dalam mengikuti pelajaran. Model pembelajaran yang diterapkan oleh guru kurang memberi kesempatan dan latihan pada siswa untuk mengungkapkan gagasan yang dimiliki, sehingga siswa yang memiliki gagasan memilih untuk diam dan tidak mencari tahu sendiri. Pada kegiatan ini juga kurang terlihat interaksi antar siswa dan interaksi siswa dan guru. Kesempatan siswa untuk bertanya atau mengemukakan pendapat masih kurang. Pada proses pembelajaran siswa belum mandiri dalam mengikuti proses pembelajaran khususnya bagi siswa yang berkemampuan rendah sehingga hasil belajarnya rendah. Siswa yang berkemampuan tinggi tetap tidak mau mengajarkan temannya yang berkemampuan rendah, sehingga hasil belajar yang baik hanya diperoleh oleh siswa yang berkemampuan tinggi. Selain itu, persaingan dalam belajar tidak ada. Keadaan ini mempengaruhi hasil belajar siswa yang masih rendah sehingga masih banyak siswa yang nilainya dibawah KKM.

Sehubungan dengan masalah diatas maka peneliti mengadakan penelitian dalam upaya untuk perbaikan proses belajar dengan model pembelajaran Think Pair Share (TPS). Think Pair Share (TPS) merupakan salah satu tipe pembelajaran yang mampu meningkatkan kemadirian siswa dalam proses belajar mengajar. Menurut Isjoni (2009: 78) pembelajaran kooperatif tipe Think Pair Share adalah teknik yang memberi siswa kesempatan untuk bekerja sendiri serta bekerja sama dengan orang lain. Dalam model pembelajaran Think Pair Share (TPS) pada proses pembelajaran menitik beratkan pada berfikir secara mandiri (think), menyampaikan idenya kepada 
teman sekelompoknya (pair), dan melatih keberanian siswa untuk mengungkapkan pendapatnya di depan kelas (share).

Tujuan penelitian ini adalah untuk meningkatkan hasil belajar dan kemandirian mata pelajaran IPA melalui model pembelajaran Think Pair Share (TPS) kelas 4 SDN Blotongan 03 semester II tahun pelajaran 2016/2017.

Ilmu Pengetahuan Alam merupakan salah satu mata pelajaran di SD yang dimaksudkan agar siswa mempunyai pengetahuan, gagasan dan konsep yang terorganisasi tentang alam sekitar, yang diperoleh dari pengalaman melalui serangkaian proses ilmiah antara lain penyelidikan, penyusunan dan penyajian gagasan-gagasan.

Sri Sulistyorini (2007:39) berpendapat bahwa mata pelajaran IPA berhubungan dengan cara mencari tahu mengenai alam secara sistematis, sehingga IPA bukan hanya penguasaan kumpulan sistematis dan IPA bukan hanya penguasaan kumpulan pengetahuan yang berupa fakta-fakta, konsep-konsep atau prinsip-prinsip saja, tetapi juga merupakan suatu proses penemuan. IPA adalah ilmu yang mempelajari peristiwa-peristiwa yang terjadi alam (Iskandar, 2001:2). Hal ini sejalan dengan itu Ilmu Pengetahuan Alam (IPA) didefinisikan sebagai kumpulan dari pengetahuan yang tersusun secara terbimbing. IPA pada kurikulum KTSP (Depdiknas, 2006) bahwa IPA berhubungan dengan cara mencari tahu tentang alam secara sistematis, sehingga bukan hanya penguasaan kumpulan pengetahuan yang berupa fakta, konsep, atau prinsip saja tetapi juga merupakan suatu proses penemuan.

Model pembelajaran Think Pair Share (TPS) memabantu siswa mandiri dalam belajar karena mereka menggali pikiran mereka sendiri hal ini sesuai dengan pendapat Anita, Lie (2005:57) yang menyatakan bahwa model ini memberikan kesepatan siswa untuk bekerja sendiri (mandiri) dan bekerjasama dengan orang lain. Model pembelajaran Think Pair Share (TPS) memabantu siswa mandiri dalam belajar karena mereka menggali pikiran mereka sendiri hal ini sesuai dengan pendapat Anita, Lie (2008:57) yang menyatakan bahwa model ini memberikan kesepatan kepada siswa untuk bekerja sendiri (mandiri) dan bekerjasama dengan orang lain. Keunggulan lain dari tehnik ini adalah optimalisasi partisipasi siswa. Model pembelajaran Think Pair Share (TPS) juga memiliki kelemahan. Anita Lie (2010:46) dalam Jumiatik (2016:137) memiliki kelemahan yaitu banyak kelompok yang melapor dan perlu monitor, jika terjadi perselisihan tidak ada penengah dalam kelompok.

Menurut Tjokrodihardjo dalam Trianto (2013: 82) langkah-langkah 
dalam model pembelajaran Think Pair Share (TPS) adalah :

a. Berfikir (thinking): Guru mengajukan pertanyaan atau masalah yang dikaitkan dengan pelajaran, dan meminta siswa menggunakan waktu beberapa menit untuk berfikir sendiri jawaban dari masalah yang diberikan.

b. Berpasangan (pairing): Guru meminta siswa untuk berpasangan dan mendiskusikan jawaban yang telah mereka peroleh. Interaksi selama waktu yang disediakan dapat menyatukan jawaban mereka. Secara normal guru memberikan waktu tidak lebih dari 4 atau 5 menit untuk berpasangan.

c. Berbagi (sharing): Pada langkah akhir, guru meminta pasangan untuk berbagi dengan temannya yang ada di kelas.

Hasil belajar adalah pola-pola pebuatan, nilai-nilai, pengertianpengertian, sikap-sikap, apresiasi dan keterampilan. Setiap kegiatan pembelajaran akan menghasilkan suatu hasil. Menurut Wardani, N.S, dkk (2012:6) hasil belajar adalah hasil yang diperoleh dari proses belajar dan hasil belajar. Hasil belajar mencakup aspek kognitif, afektif, dan psikomotorik. Hasil belajar diperoleh dari hasil tes dan non tes. Dengan demikian, hasil belajar siswa dapat diperoleh guru dengan terlebih dahulu memberikan seperangkat tes kepada siswa untuk menjawabnya. Hasil tes belajar siswa akan memberikan gambaran informasi tentang kemampuan dan penguasaan kompetensi siswa pada suatu materi pelajaran yang kemudian dikonversi dalam bentuk angka-angka.

Haris Mudjiman (2007:7) menyebut istilah kemandirian belajar dengan belajar mandiri. Belajar mandiri adalah kegiatan belajar aktif, yang didorong oleh niat atau motiv untuk menguasai sesuatu kompetensi guna mengatasi sesuatu masalah, dan dibangun dengan bekal pengetahuan atau kompetensi yang telah dimiliki. Dari berbagai pengertian tersebut, kemandirian belajar dalam penelitian ini dibatasi pada kemandirian belajar di kelas, khususnya pada mata pelajaran IPA. Kemandirian belajar yang dimaksud adalah proses kegiatan belajar dimana siswa dapat mengambil inisiatif sendiri tanpa tergantung dengan orang lain untuk menentukan tujuan belajar, mengidentifikasi sumber belajar, dan melakukan evaluasi hasil belajar yang dicapai pada mata pelajaran IPA.

Setiap hari siswa sering dihadapkan pada permasalahan yang menuntut siswa untuk mandiri dan menghasilkan suatu keputusan yang baik. Song and Hill dalam Arfiani, Wiwik (2015:4) menyebutkan bahwa kemandirian terdiri dari beberapa aspek, yaitu: 
1. Personal Attributes

Personal attributes adalah aspek yang berkenaan dengan motivasi dari pebelajar, penggunaan sumber belajar, dan strategi belajar. Motivasi belajar merupakan keinginan dari diri seseorang yang merangsang untuk melakukan kegiatan belajar. Ciri-ciri dari motivasi menurut Worrel dan Stillwell antara lain: tanggungjawab, tekun terhadap waktu penyelesaian, menetapkan tujuan yang realitas.

\section{Processes}

Processes adalah aspek yang berkenaan dengan susunan proses pembelajaran yang dilakukan oleh pebelajar meliputi perencanaan, monitoring, serta evaluasi pembelajaran. Kegiatan perencanaan meliputi: mengelola waktu secara efektif, menentukan prioritas dan menata diri.

\section{Learning Context}

Learning context berfokus pada faktor lingkungan dan bagaimana faktor tersebut mempengaruhi tingkat kemandirian pebelajar. Ada beberapa faktor dalam konteks pembelajaran yang dapat mempengaruhi pengalaman mandiri pembelajar antara lain, structure dan nature of task. Struktur dan tugas dalam konteks pembelajaran ini misalnya, siswa belajar dengan struktur (cara kerja) model pembelajaran kooperatif tipe Think Pair Share (TPS) dan mengerjakan tugas kelompok dalam LKS.

Berdasarkan pendapat-pendapat di atas dapat disimpulkan bahwa kemandirian belajar siswa memiliki aspek-aspek, yaitu personal attributes, processes, dan learning context. Dalam kegiatan pembelajaran IPA kemandirian belajar dapat dilihat melalui: (1) memiliki motivasi belajar, (2) memiliki kepercayaan diri, (3) bertanggungjawab dalam mengerjakan tugas, (4) memanfaatkan sumber belajar secara optimal, (5) mengevaluasi hasil belajar.

\section{METODE PENELITIAN}

Jenis penelitian ini adalah Penelitian Tindakan Kelas (PTK). Langkah-langkah penelitian untuk setiap siklus perlakuan pembelajaran IPA diilustrasikan sebagai berikut:

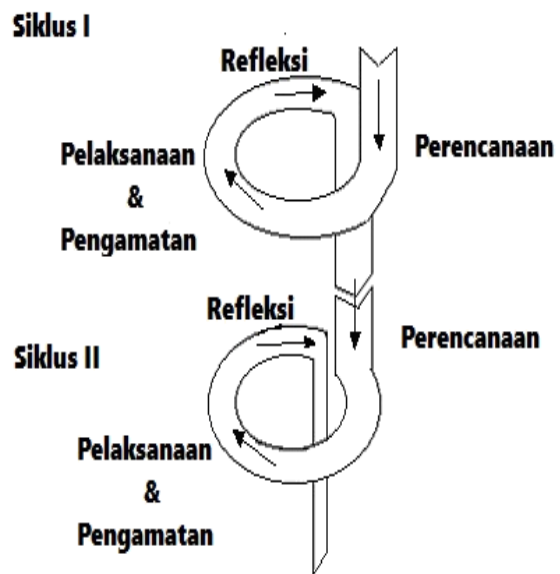

\section{Gambar. Bagan Proses Penelitian Tindakan Kelas}

Teknik pengumpulan data pada penelitian ini yaitu dengan observasi, tes, dan angket. Observasi 
dilakukan terhadap proses pembelajaran dengan menggunakan model pembelajaran Think Pair Share (TPS). Teknik Tes adalah serentetan pertanyaan latihan yang digunakan untuk mengukur ketrampilan, pengetahuan intelegensi, dan kemampuan atau bakat yang dimiliki oleh individu atau kelompok (Suharsimi Arikunto, 2006:150). Pada penelitian ini menggunakan tes formatif. Tes formatif untuk mengukur hasil belajar siswa. Angket digunakan untuk mengukur kemandirian siswa. Angket untuk mengukur tingkat kemandirian siswa. Angket yang peneliti adalah angket tertutup, dimana pengisiannya hanya memberikan tanda centang $(\checkmark)$ dari beberapa item yang telah ditentukan oleh peneliti.

Dalam penelitian ini, peneliti menggunakan tes, observasi, dan angket untuk mengumpulkan data. Teknik analisis data pada penelitian ini adalah teknik analisis data deskriptif kuantitatif. Data yang sudah diperoleh dan diolah kemudian disimpulkan bagaimana hasil belajar dan kemandirian siswa.

\section{HASIL DAN PEMBAHASAN}

Peneliti melakukan observasi awal sebelum melakukan tindakan penelitian. Hasil dari observasi menunjukkan bahwa dalam prestasi belajar IPA khususnya kelas 4 tergolong rendah dan menggunakan model pembelajaran konvensional.
Hal ini disebabkan dengan penggunaan metode ceramah siswa masih pasif, tidak membuat siswa mandiri, tidak ada kerjasama antar siswa sehingga siswa merasa bosan dan kurang tertarik saat proses pembelajaran yang pada akhirnya mempengaruhi hasil belajar siswa. Hal ini terbukti dari 24 jumlah siswa kelas 4 terdapat 10 siswa belum tuntas atau tidak mencapai nilai KKM ( $\geq 70$ ) dengan persentase $41,7 \%$ dan 14 siswa tuntas dengan prosentase $58,3 \%$, dengan nilai rata-rata 62,70 . Tingkat kemandirian siswa juga tergolong rendah, hal ini dibuktikan dengan rendahnya persentase hasil angket kemandirian siswa. Pada pra siklus jumlah peserta didik yang berada pada kualifiklasi cukup ada 23 siswa $(95,8 \%)$ dan pada kategori baik ada 1 siswa (4,2\%). Nilai terendahnya yang diperoleh 43, nilai tertinggi yang diperoleh 59, dan rata-ratanya adalah hanya 48,5. Hal ini disebabkan oleh cara guru dalam mengajar masih menggunakan metode konvensional atau ceramah yang mengakibatkan siswa pasif, proses pembelajaran sebelum adanya tindakan banyak siswa pasif dan bosan karena pembelajaran yang monoton sehingga mengakibatkan siswa kurang mandiri dan hasil belajar siswa rendah.

Sebagai salah satu cara untuk mengatasi rendahnya hasil belajar dan kemandirian siswa, peneliti menggunakan model pembelajaran kooperatif tipe Think Pair Share 
(TPS). Menurut Isjoni (2009:78) pembelajaran kooperatif tipe Think Pair Share adalah teknik yang memberi siswa kesempatan untuk bekerja sendiri serta bekerja sama dengan orang lain. Dalam model pembelajaran Think Pair Share (TPS) pada proses pembelajaran menitik beratkan pada berfikir secara mandiri (think), menyampaikan idenya kepada teman sekelompoknya (pair), dan melatih keberanian siswa untuk mengungkapkan pendapatnya di depan kelas (share). Think Pair Share (TPS) adalah salah satu model pembelajaran yang melibatkan aktivitas seluruh siswa dan membuat siswa mandiri dan berani mengungkapan setiap ide yang mereka miliki. Model pembelajaran Think Pair Share (TPS) memabantu siswa mandiri dalam belajar karena mereka menggali pikiran mereka sendiri. Sejalan dengan teori tersebut penelitian ini dilakukan untuk mengetahui peningkatan hasil belajar dan kemandirian belajar dengan model pembelajaran Think Pair Share (TPS). Pada model pembelajaran Think Pair Share (TPS) guru memberikan pertanyaan atau soal kepada siswa yang mereka pikirkan sendiri-sendiri kurang lebih 2-5 menit (think), kemudian siswa diminta untuk mendiskusikan jawaban atau pendapatnya secara berpasangan dengan teman yang duduk disebelahnya (pair). Selain itu guru dapat menunjukkan satu atau lebih siswa untuk menyampaikan pendapatnya atas pertanyaan tersebut keseluruh siswa di kelas (share). Kegiatan pada pembelajaran Think Pair Share (TPS) akan membuat siswa menjadi lebih mandiri karena pada saat pembelajaran siswa yang dapat mengambil inisiatif sendiri, tanpa tergantung dengan orang lain, untuk menentukan tujuan belajar, mengidentifikasi sumber belajar, dan melakukan evaluasi hasil belajar yang dicapai pada mata pelajaran IPA.

Setelah dilakukan penelitian, pada siklus satu terjadi peningkatan hasil belajar siswa dengan rata - rata menjadi 75,62. Dari jumlah siswa 24, ada 18 anak dengan prosentase $75 \%$ siswa sudah tuntas atau mencapai nilai KKM $(\geq 70)$ dan masih ada 6 atau $25 \%$ siswa yang belum tuntas. Tingkat kemandirian siswa juga mengalami peningkatan, pada siklus I jumlah peserta didik yang berada pada kualifikasi cukup ada 18 siswa (75\%) dan pada kategori baik ada 6 siswa (25\%). Nilai terendahnya yang diperoleh 49, nilai tertinggi yang diperoleh 67, dan rata-ratanya meningkat menjadi 57,7. Ini artinya pada siklus 1 terjadi peninkatan, tapi sayangnya peninkatan ini belum memenuhi kriteria keberhasilan, yaitu $80 \%$. Hal ini disebabkan pada siklus satu siswa masih ramai dalam kegiatan pembelajaran, waktu kurang efisien, model pembelajaran kurang membuat siswa antusias dalam mengikuti pembelajaran, dan ada 
beberapa anak yang masih belum percaya diri ketika maju kedepan kelas untuk menyampaikan hasil diskusinya.

Kekurangan yang terjadi pada siklus satu dilakukan perbaikan pada siklus dua. Siswa yang tadinya masih ramai, pada siklus dua guru sudah dapat menkondisikan kelas, sehingga kelas menjadi kondusif. Pada proses kegiatan belajar siswa yang dapat mengambil inisiatif sendiri, tanpa tergantung dengan orang lain, untuk menentukan tujuan belajar, mengidentifikasi sumber belajar, dan melakukan evaluasi hasil belajar yang dicapai pada mata pelajaran IPA. Pemanfaatan waktu pada siklus dua juga lebih efisien karena kelas dapat dikondisikan dengan baik. Pada siklus satu anak-anak yang belum percaya diri ketika maju ke depan kelas menyampaikan pendapat menjadi berani menyampaikan pendapatnya di depan kelas, bahkan siswa pada siklus dua lebih memperhatikan kemlompok lain ketika kelompok lain menyampaikan hasil diskusinya di depan kelas.

Hasil dari siklus II, siswa mengalami ketuntasan pada mata pelajaran IPA mencapai 91,6\% karena ada dua anak yang belum tuntas, hal yang harus guru lakukan memberikan jam tambahan supaya mereka menjadi lebih mengerti dan bisa tuntas. Pada siklus dua rata-rata menjadi 83,75 dengan nilai tertinggi 100 . Terjadi peningkatan persentase pada siklus II.
Hasil kemandirian siswa pada siklus II jumlah peserta didik yang berada pada kualifikasi cukup sudah tidak ada, pada kategori baik ada 2 siswa $(8,4 \%)$ dan pada kateori sangatbaik ada 22 siswa (91,6\%). Nilai terendahnya yang diperoleh 69 , nilai tertinggi yang diperoleh 79 , dan rata-ratanya adalah hanya 73,2.

Pengunaan model pembelajaran tipe Think Pair Share (TPS) ternyata dapat memberikan pembelajaran yang menarik. Hasil penamatan selama proses pembelajaran kemandirian siswa cukup besar. Siswa memiliki motivasi untuk belajar, antusias dan aktif dalam pembelajaran, memikili rasa kepercayaan diri yang tinggi, bertangungjawab dalam mengerjakan tugas, siswa juga memanfaatkan sumber belajar secara optimal, siswa juga terbiasa mengevaluasi hasil belajarnya. Hal-hal ini dapat berdampak pada nilai pembelajaran siswa yang meningkat. Kelebihan pada penelitian ini, merangsang kreatifitas siswa untuk mengungkapkan idenya, siswa diajak untuk berdisi bersama-sama dan diberi kebebasan mnengemukakan idenya saat diskusi berlangsung dan siswa terlibat langsung dalam proses pembelajaran, tidak hanya menjadi pendengar saja, tetapi juga melakukan. Karena itulah siswa menjadi semakin percaya diri. Peneliti mengunakan vidio pembelajaran dan gambar sehingga siswa menjadi lebih 
antusias dalam kegiatan pembelajaran. Pembelajaran tidak hanya berada di dalam kelas tapi juga di luar kelas, sehingga pembelajaran tidak monoton guru mengajak siswa untuk belajar dengan lingkungan sekitar. Jadi siswa menjadi lebih mengerti tentang lingkungannya dan dapat memanfaatkan lingkungan dengan bijak. Meningkatkan aspek kemandirian siswa.

\section{Berdasarkan hasil penelitian di} atas dapat diketahui terjadi peningkatan hasil belajar dan kemandirian siswa melalui model pembelajran tipe Think Pair Share (TPS) mata pelajaran ilmu pengetahuan alam pada siswa kelas 4 di SDN Blotongan 03 Kecamatan Sidorejo kota Salatiga tahun ajaran 2016/2017 semester II.

\section{SIMPULAN}

Berdasarkan hasil penelitian dan pembahasan yang disajikan dalam BAB IV dapat disimpulkan sebagai beriku:

1. Langkah-langkah pembelajaran model pembelajaran think Pair Share (TPS) yang terbukti meningkatkan hasil belajar dan kemadirian siswa adalah (1) Guru menyampaikan kompetensi dan inti materi yang akan dicapai (2) Siswa berfikir (Think) tentang permasalahan yang disampaikan guru (3) Siswa duduk berpasangan (Pairs) dengan mendiskusikan permasalahan (4) Setiap pasangan berbagi (Sharing) tentang permasalahan dan pemecahan masalah tersebut yang dirumuskan di depan kelas (5) Siswa menyimak penegasan permasalahan oleh guru (6) Menyimak kesimpulan (7) Penutup.

2. Penggunaan model pembelajaran kooperatif tipe Think Pair Share (TPS) dapat meningkatkan hasil belajar IPA siswa kelas 4 SD N Blotongan 03 Kecamatan Sidorejo Kota Salatiga Semester II Tahun Pelajaran 2016/2017. Hal ini trelihat dari ketuntasan hasil belajar siswa yang mulanya pada pembelajaran prasiklus tingkat ketuntasan hasil belajar sebesar $58,3 \%$ rata-rata 62,70 dengan nilai maksimal 85 dan nilai minimum 20. Sedangkan pada pembelajaran siklus I dengan tingkat ketuntasan hasil belajar $75 \%$ rata-rata 75,62 , dengan nilai maksimum 95 dan minimum 50. Dan dengan adanya pembelajaran pada siklus II ketuntasan hasil belajar 91,6\% ada dua anak yang belum tuntas, guru dapat memberikan bimbingan lebih setelah jam pembelajaran untuk kedua anak ini. Rata-rata nilai sisiwa pada siklus dua adalah 83,75 dengan nilai maksimum 100 dan nilai minimum 60 .

3. Penggunaan model pembelajarn kooperetif tipe Think Pair Share (TPS) dapat meningkatkan kemandirian siswa kelas 4 SD N 
Blotongan 03 Kecamatan Sidorejo Kota Salatiga Semester II Tahun Pelajaran 2016/2017. Hal ini dapat dilihat dengan hasil angket kemandirian yang menunjukkan Pada pra siklus jumlah peserta didik yang berada pada kualifikasi "cukup" ada 23 siswa $(95,8 \%)$ dan pada kategori "baik" ada 1 siswa $(4,2 \%)$. Nilai terendahnya yang diperoleh 43 , nilai tertinggi yang diperoleh 59, dan rata- ratanya adalah hanya 48,5 . Pada siklus satu tingkat kemandirian siswa mengalami peningkatan, pada siklus I jumlah peserta didik yang berada pada kualifikasi "cukup" ada 18 siswa (75\%) dan pada kategori "baik" ada 6 siswa (25\%). Nilai terendahnya yang diperoleh 49 , nilai tertinggi yang diperoleh 67, dan rata-ratanya meningkat menjadi 57,7. Ini artinya pada siklus I terjadi peninkatan, tapi sayangnya peningkatan ini belum memenuhi kriteria keberhasilan, yaitu $80 \%$. Terjadi peningkatan prosentase pada siklus II. Pada siklus II jumlah peserta didik yang berada pada kualifikasi cukup sudah tidak ada, pada kategori "baik" ada 2 siswa $(8,4 \%)$ dan pada kateori "sangat baik" ada 22 siswa $(91,6 \%)$. Nilai terendahnya yang diperoleh 69 , nilai tertinggi yang diperoleh 79, dan rataratanya adalah 73,2 .
Berdasarkan hasil penelitian yang telah dilakukan diketahui bahwa penerapan model pembelajaran kooperatif tipe Think Pair Share (TPS) dapat meningkatkan hasil belajar dan kemandirian siswa. Oleh sebab itu penulis menyarankan : (1) bagi Sekolah Pendidikan sekolah harus memantau proses kegiatan pembelajaran yang dilaksanakan oleh guru di kelas agar diketahui seberapa efektif model pembelajaran yang sudah diterapkan, serta mengetahui pengaruh model pembelajaran yan digunakan guru terhadap hasil belajar dan kemandirian siswa, (2) kepada para guru, guru hendaknya menerapkan beragam model pembelajaran yang membuat siswa semangat dalam belajar supaya siswa tidak bosan dengan pembelajaran. Siswa juga perlu diajarkan untuk berfikir mandiri supaya siswa tidak perlu bergantung pada guru dan hasil belajar dapat meningkat sesuai KKM, bahkan melebihi KKM dan kemandirian siswa dapat meningkat. Guru hendaknya memotivasi siswa agar merasa percaya diri sehinga siswa dapat mengembangkan potensi yang dimiliki dan dapat mengeluarkan setiap pendapat dan bertanya tanpa rasa takut.

\section{DAFTAR RUJUKAN}

Anita, Lie. 2008. Cooperative Learning. Jakarta: Gramedia Widiasarana Indonesia (Grasindo). 
Arikunto, Suharsimi. 2006. Penelitian Tindakan Kelas. Jakarta: Bumi Aksara.

Ariyani, Wiwik. 2015. Hubungan Antara Persepsi terhadap layanan bimbingan konseling dengan kemandirian belajar pada siswa. Naskah Publikas: Universitas Muhammadiyan Surakarta.

Depdiknas. 2006. Kurikulum Satuan Tingkat Pendidikan. Jakarta: Depdiknas.

Isjoni, 2009. Cooperative Learnin Efektifitas Pembelajaran Kelompok. Bandung: Alfabeta.

Iskandar. (2001). Pendidikan Ilmu Pengetahuan Alam. Bandung: CV. Maulana.

Jumiatik. 2016. Upaya Meningkatkan Aktivitas Belajar Siswa Melalui Penerapan

Model Pembelajaran Kooperatif Tipe
Think Pair Share Pada Mata Pelajaran Matematika Di Kelas VI SD Negeri No. 050611 Aman Damai. ELEMENTARY SCHOOL JURNAL PGSD FIP UNIMED. 6 (2).

Mudjiman, Haris. 2007. Belajar Mandiri (Self-Motivated Learning). Surakarta: LPP UNS dan UNS Press.

Sulistyo, S. 2007. Model Pembelajaran IPA Sekolah Dasar Dan Penerapannya Dalam KTSP. Semarang: Tiara Wacana.

Trianto. 2013. Model-Model Pembelajaran Inovatif Berorientasi Konstruktivitis. Jakarta: Prestasi Pustaka Publiser.

Wardani, N.S, dkk. 2012. Evaluasi Proses Pembelajaran dan Hasil Belajar. Salatiga: Penerbit Widya Sari Press. 